\title{
Incidence of neural tube defects and their risk factors within a cohort of Moroccan newborn infants
}

Khenata Forci $^{1 *} \mathbb{D}$, El Arbi Bouaiti ${ }^{2}$, Mohamed Hassan Alami ${ }^{1,3}$, Asmaa Mdaghri Alaoui ${ }^{1,4}$ and Amal Thimou Izgua ${ }^{1,5}$

\begin{abstract}
Background: Neural tube defects (NTDs) are a group of birth defects that result from a partial or complete failure of the neural tube to close during embryogenesis. Their prevalence varies between 0.5 to 2 per 1000 births in countries without folic acid supplementation. The aim of our study is to assess the NTDs incidence and describe the risk factors within Moroccan newborn infants.

Method: This is a descriptive study over a period of 5 and a half years including all births at "Les Orangers" Maternity and Reproductive Health Hospital of Rabat with notification of NTD cases, whether isolated or combined with other anomalies. Data were reported on pre-established sheets and on the teratovigilance registry. Statistical analysis was performed with SPSS version 18 statistical software.

Results: During the study period, 43,923 births were recorded including 44 cases of neural tube defects, an incidence rate of 1 per 1000 births, with a female predominance; sex ratio $=0.8$. These defects included anencephaly (50\%), spina bifida (38.6\%) and encephalocele (11.4\%). The risk factors detected during this study include consanguinity (34\%), consumption of fenugreek or other plants (36\%), diabetes (4.5\%) and medication (2.2\%). A family history of malformation was reported in $6.8 \%$ of cases and among siblings in $4.5 \%$ of cases. The average maternal age was $30.38 \pm 6.88$ and the average gestational age was $36.80 \pm 5.11$. A quarter of mothers did not benefit from any medical monitoring during pregnancy while $59 \%$ did not take folic acid supplementation during the first trimester of pregnancy and none of them took B9 vitamin during the periconceptional period. The antenatal diagnosis was performed in $63 \%$ of cases. The mortality rate was 3.8 per 10,000 and $16 \%$ of cases evolved positively.
\end{abstract}

Conclusion: NTDs require high intensity and multidisciplinary care which stresses the importance, in our context, of strengthening and optimizing acid folic supplementation strategies during the periconceptional period.

Keywords: Incidence, Morocco, Neural tube defects, Prevention, Risk factors

\footnotetext{
* Correspondence: docteurforcikhenata@gmail.com

${ }^{1}$ Congenital Defects Research Team, Faculty of Medicine and Pharmacy,

University Mohamed V Rabat, P.B: 174 Downtown Rabat, Rabat, Morocco

Full list of author information is available at the end of the article
}

(c) The Author(s). 2021 Open Access This article is licensed under a Creative Commons Attribution 4.0 International License, which permits use, sharing, adaptation, distribution and reproduction in any medium or format, as long as you give appropriate credit to the original author(s) and the source, provide a link to the Creative Commons licence, and indicate if changes were made. The images or other third party material in this article are included in the article's Creative Commons licence, unless indicated otherwise in a credit line to the material. If material is not included in the article's Creative Commons licence and your intended use is not permitted by statutory regulation or exceeds the permitted use, you will need to obtain permission directly from the copyright holder. To view a copy of this licence, visit http://creativecommons.org/licenses/by/4.0/ The Creative Commons Public Domain Dedication waiver (http://creativecommons.org/publicdomain/zero/1.0/) applies to the data made available in this article, unless otherwise stated in a credit line to the data. 


\section{Introduction}

Neural tube defects (NTDs) are congenital malformations that appear at the embryonic development stage, between the 23rd and 27th day of embryonic life. They vary from a simple spina bifida to a complete anencephalomyelia. Structural malformations at the development level can affect the thoracic, lumbar or sacral (spina bifida) spines as well as the skull (anencephaly or encephalocele), while secondary joint-anomalies (rupture or deformation) can affect the lower limbs, the intestines, the bladder, the cerebellum and the cortex or the brain ventricles (in the case of myelomeningocele). Worldwide, NTDs affect 323,904 infants [1] and cause 88,000 deaths every year in addition to leaving 8.6 million people with disabilities $[2,3]$, and they are the cause behind $29 \%$ of neonatal deaths in low-income countries [4]. The prevalence of these malformations ranges from 0.5 to 2 per 1000 births in countries without folic acid supplementation [5]. The etiologies of these anomalies are complex and include several genetic as well as environmental factors. Our study aims are to assess the NTDs' incidence and describe the risk factors within Moroccan newborn infants.

\section{Method}

\section{Study design}

This is a prospective study, based on the notification of all cases presenting an anomaly of NTD isolated or associated with other anomalies within the Maternity and Reproductive Health Hospital "Les Orangers" in Rabat from January 1st, 2011 as of June 30th, 2016; it's a level III-reference maternity which receives pregnant women from all over Morocco and performs 8000 deliveries per year. Normal and high-risk pregnancies are managed and monitored within the maternity following standardized protocols including antenatal checkups and obstetrical ultrasounds. Within this study, we have included all women whose fetus or newborn showed an isolated or combined neural tube defect, whether diagnosed through a prenatal ultrasound or the systematic clinical exam at birth, regardless of the pregnancy term or outcome.

\section{Data collection}

Once a case has been confirmed, the doctor approaches the parents to explain the baby's situation and provide a prognosis. He also explains the method and objectives of our study in order to obtain an informed parents' consent. A majority of the interviewed women are illiterate and, for cultural reasons, they have provided a verbal (i.e. without signature) consent to participate in the study. Each couple has provided his consent after receiving the necessary explanations from a three-person team of medical personnel. All collected data; anamnesis, socioeconomic status, consanguinity, history of malformations within the family or siblings, exposition to teratogens, mother's serology, pregnancy characteristics in addition to the newborn's characteristics were reported on pre-established sheets and on the teratovigilance registry. The evaluation of the prognosis of these newborns was based on monitoring the short-term progress (6 months). An outcome presented in the evolution indicates the survival rate at 6 months of cases whether they are operated on or not yet.

\section{Definitions}

Neural tube defects include: [6].

- Exencephaly / anencephaly: is an anterior neuropore closure anomaly with the neural tube in a state of neural tube, with an extracranial protrusion of the brain. The latter will suffer from aggression and decay due to the contact with amniotic fluid to cause anencephaly.

- Myelomeningocele / spina bifida: a more or less extensive cord closure abnormality, causing the posterior arches of the thoracic, lumbar or sacral spine to open.

- Encephalocele / meningocele: is a developmental defect of the mesoblast leading to an opening of the skull with herniation of the meninges. It can be occipital, parietal or fronto-ethmoidal.

\section{Statistical analysis}

The statistical analysis for this descriptive epidemiological study was performed with SPSS version 18 statistical software. Quantitative variables are expressed in averages $+/$ - standard deviation and qualitative variables in numbers and percentages.

\section{Results}

During the study period from January 1st, 2011 to June 30th, 2016, 43,923 births were recorded including 44 cases of neural tube defects; an incidence rate of 1 per 1000 births, this incidence rate varied throughout the years with 2 peaks. A first peak was recorded in 2012 with an estimated incidence rate of 1.8 per 1000 births (the highest rate recorded during the study period) and a second peak in 2015 with an incidence rate of 1.3 per 1000 births. The reported incidence rate for the 6month period in 2016 was 0.5 (Fig. 1).

The incidence rates for the various types of NTDs highlights 2 peaks of anencephaly and Spina Bifida; the first one in 2012 with an incidence rate of 6 per 1000 births and the second one in 2015 with an estimated rate of 5-6 per 1000 births. Encephaloceles' incidence peaked twice in 2012 and 2014 with an estimated rate of 2 per 1000 births. (Fig. 2). 


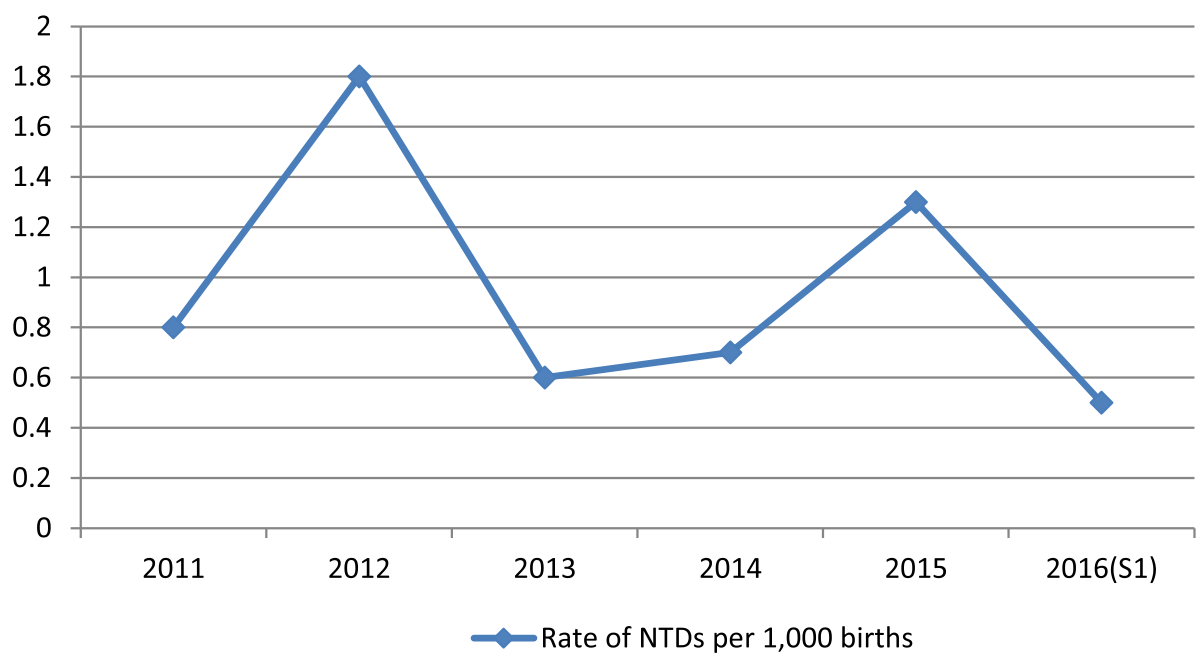

Fig. 1 Yearly incidence rates of NTDs at "Les Orangers" Maternity and Reproductive Health Hospital of Rabat, Morocco. S1 = first semester

Half of reported defects were anencephaly (50\%), followed by spina bifida (38.6\%) and encephalocele (11.4\%). Thus, the incidence rates of anencephaly, spina bifida and encephalocele were respectively 5 , 3.8 and 1.1 per 10,000 births with a female predominance especially for anencephaly (sex ratio $=0.75$ ) and encephalocele (0.33) while we noted a male predominance for spina bifida (1.33). Certain risk factors for NTDs described in the literature were detected in our series (Table 1), such as consanguinity wich was reported in $34 \%$ of cases, consumption of fenugreek and other plants in $36 \%$ of cases, diabetes in $4.5 \%$ and medication in $2.2 \%$. A history of malformation was reported in the family for $6.8 \%$ of cases and among siblings for $4.5 \%$. Half of women came from a low socioeconomic status, especially in anencephaly cases. The average maternal age was $30.38 \pm 6.88$ and the average gestational age was $36.80 \pm 5.11$. A quarter of mothers did not benefit from medical monitoring during pregnancy while $59 \%$ did not take folic acid supplementation during the first trimester of pregnancy and none of them took B9 vitamin during the periconceptional period. The antenatal diagnosis was performed in $63 \%$ of cases, with only 4 cases (9.1\%) choosing a therapeutic interruption of pregnancy. We resorted to a caesarean section in 7 cases of NTDs.

The NTDs were combined with other malformations in $45.4 \%$ of cases (Table 2). Regarding the evolution of NTD cases, the 6-month survival rate is $16 \%$ represented by the 7 cases of spina bifida (Table 3).

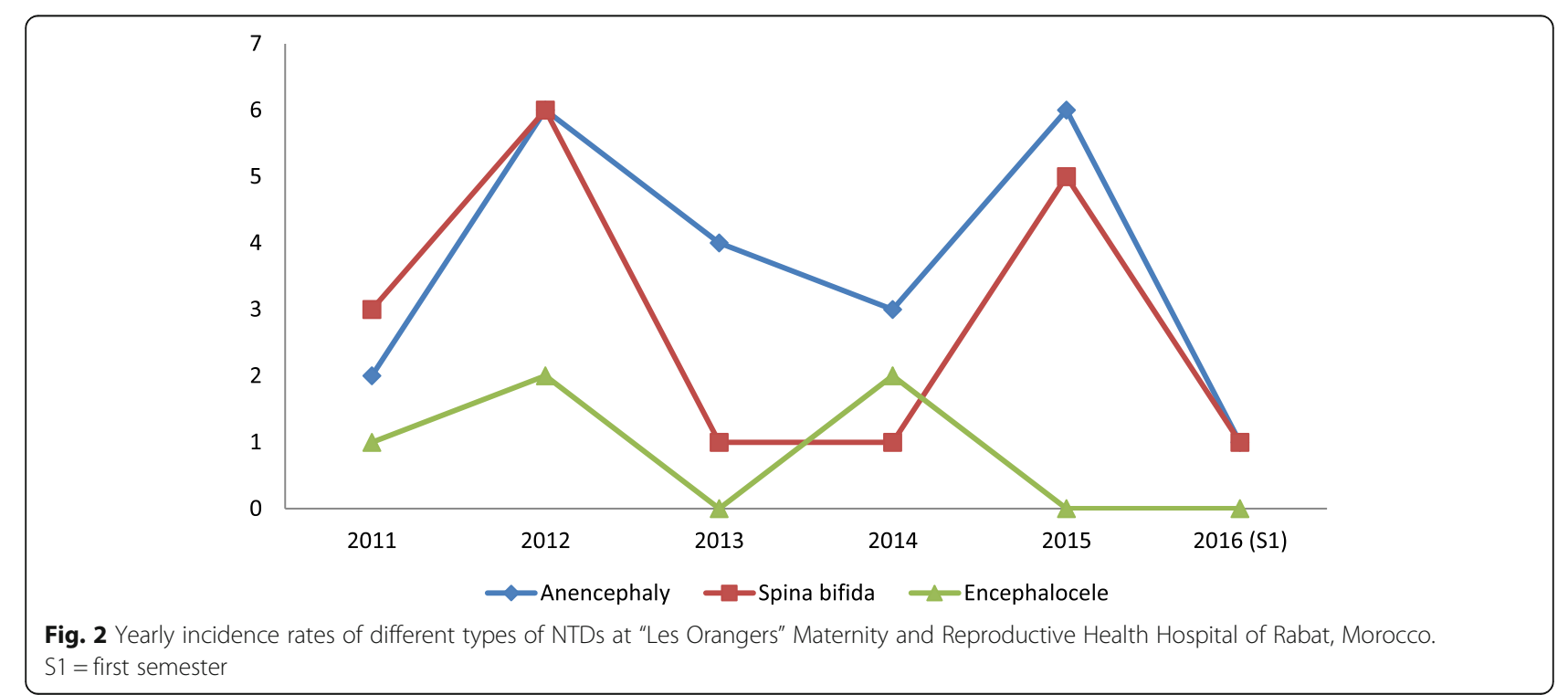


Table 1 Social, demographic and obstetrical characteristics of deformed newborns' mothers and main risk factors at "Les Orangers" Maternity and Reproductive Health Hospital of Rabat, Morocco

\begin{tabular}{|c|c|c|c|c|}
\hline & 44 cases of NTDs & $\begin{array}{l}\text { Anencephaly } \\
22(50 \%)\end{array}$ & $\begin{array}{l}\text { Spina Bifida } \\
17(38.6 \%)\end{array}$ & $\begin{array}{l}\text { Encephalocele } \\
5(11.4 \%)\end{array}$ \\
\hline \multicolumn{5}{|l|}{ Maternel age } \\
\hline$<35$ years & $33(75)$ & $16(72.7)$ & $14(82.4)$ & $3(60)$ \\
\hline$\geq 35$ years & $11(25)$ & $6(27.3)$ & $3(17.6)$ & $2(40)$ \\
\hline \multicolumn{5}{|l|}{ Socio-economic level } \\
\hline Low & $26(59)$ & $12(54.5)$ & $11(64.7)$ & $3(60)$ \\
\hline Middle & $15(34)$ & $8(36.4)$ & $5(29.4)$ & $2(40)$ \\
\hline High & $3(6.8)$ & $2(9.1)$ & $1(5.9)$ & 0 \\
\hline Consanguinity & $15(34)$ & $7(31.8)$ & $5(29.4)$ & $3(60)$ \\
\hline First degree & $12(27)$ & $5(22.7)$ & $5(29.4)$ & $2(40)$ \\
\hline Second degree & $3(6.8)$ & $2(9)$ & 0 & $1(20)$ \\
\hline Third degree & 0 & 0 & 0 & 0 \\
\hline \multicolumn{5}{|l|}{ Medical history } \\
\hline Diabetes & $1(2.27)$ & $1(4.5)$ & 0 & 0 \\
\hline Gestational Diabetes & $1(2.27)$ & 0 & $1(5.9)$ & 0 \\
\hline Malformation history in siblings & $2(4.5)$ & $1(4.5)$ & 0 & $1(20)$ \\
\hline Malformation history in family & $3(6.8)$ & $2(9.1)$ & 0 & $1(20)$ \\
\hline Fenugreek consumption & $10(22.7)$ & $8(36.4)$ & $2(11.8)$ & 0 \\
\hline Other plants consumption & $6(13.6)$ & $5(22.7)$ & $1(5.9)$ & 0 \\
\hline \multicolumn{5}{|l|}{ Medication } \\
\hline Paracetamol & $1(2.27)$ & 0 & $1(5.9)$ & 0 \\
\hline \multicolumn{5}{|l|}{ Folic acid supplementation } \\
\hline In preconception & 0 & 0 & 0 & 0 \\
\hline During the first trimester & $11(25)$ & $5(22.7)$ & $5(29)$ & $1(20)$ \\
\hline Pregnancy follow-up & $33(75)$ & $15(68.2)$ & $14(82.4)$ & $4(80)$ \\
\hline \multicolumn{5}{|l|}{ Gestational age } \\
\hline$\leq 21 \mathrm{WA}$ & $3(6.8)$ & 0 & $2(11.8)$ & $1(20)$ \\
\hline 22-36WA & $9(20.4)$ & $6(27.3)$ & $2(11.8)$ & $1(20)$ \\
\hline$\geq 37 \mathrm{WA}$ & $32(72.7)$ & $16(72.7)$ & $13(76.4)$ & $3(60)$ \\
\hline Prenatal diagnosis & $28(63)$ & $17(77.3)$ & $8(47.1)$ & $3(60)$ \\
\hline \multicolumn{5}{|l|}{ Mode of delivery } \\
\hline Normal & $36(81.8)$ & $20(90.9)$ & $11(68.8)$ & $5(100)$ \\
\hline Caesarean section & $7(16)$ & $2(9.1)$ & $5(31.2)$ & 0 \\
\hline TIP & $4(9.1)$ & $2(9.1)$ & $1(5.9)$ & $1(20)$ \\
\hline
\end{tabular}

NTDs neural tube defects, \% percentage, WA week of amenorrhea, TIP therapeutic interruption of pregnancy

Table 2 Distribution of NTD cases between isolated and combined with other congenital malformations at "Les Orangers" Maternity and Reproductive Health Hospital of Rabat, Morocco

\begin{tabular}{|c|c|c|c|c|c|c|}
\hline \multirow[t]{2}{*}{ NTDs } & \multicolumn{2}{|c|}{ Total Number of cases } & \multicolumn{2}{|c|}{ Isolated NTDs } & \multicolumn{2}{|c|}{ Associated NTDs } \\
\hline & Number & $\%$ & Number & $\%$ & Number & $\%$ \\
\hline Anencephaly & 22 & 50 & 18 & 81.8 & 4 & 18.2 \\
\hline Spina Bifida & 17 & 38.6 & 4 & 23.5 & 13 & 76.5 \\
\hline Encephalocele & 5 & 11.4 & 2 & 40 & 3 & 60 \\
\hline
\end{tabular}

NTDs neural tube defects, $\%$ percentage 
Table 3 Newborns' characteristics and outcomes at "Les Orangers" Maternity and Reproductive Health Hospital of Rabat, Morocco

\begin{tabular}{|c|c|c|c|c|}
\hline & $\begin{array}{l}\text { NTDs (44) } \\
\text { N (\%) }\end{array}$ & $\begin{array}{l}\text { Anencephaly } \\
22(50 \%)\end{array}$ & $\begin{array}{l}\text { Spina bifida } \\
17(38.6 \%)\end{array}$ & $\begin{array}{l}\text { Encephalocele } \\
5(11.4 \%)\end{array}$ \\
\hline \multicolumn{5}{|l|}{ Newborn sex } \\
\hline Feminine & $22(50)$ & $13(59.1)$ & $6(35.3)$ & $3(60)$ \\
\hline Male & $19(43.2)$ & $9(40.9)$ & $9(53)$ & $1(20)$ \\
\hline Ambiguity & $3(6.8)$ & 0 & $2(11.7)$ & $1(20)$ \\
\hline \multicolumn{5}{|l|}{ Gestational age } \\
\hline$\leq 21 \mathrm{WA}$ & $3(6.8)$ & 0 & $2(11.8)$ & $1(20)$ \\
\hline 22-36WA & $9(20.4)$ & $6(27.3)$ & $2(11.8)$ & $1(20)$ \\
\hline$\geq 37 \mathrm{WA}$ & $32(72.7)$ & $16(72.7)$ & $13(76.4)$ & $3(60)$ \\
\hline \multicolumn{5}{|l|}{ Mode of delivery } \\
\hline Normal & $36(81.8)$ & $20(90.9)$ & $11(68.8)$ & $5(100)$ \\
\hline Cesarean section & $7(16)$ & $2(9.1)$ & $5(31.2)$ & 0 \\
\hline \multicolumn{5}{|l|}{ Birth weight } \\
\hline$<2500 \mathrm{~g}$ & $26(59)$ & $15(68.2)$ & $7(41.2)$ & $4(80)$ \\
\hline$[2500 ; 4000 \mathrm{~g}]$ & $15(34)$ & $6(27.3)$ & $8(47.1)$ & $1(20)$ \\
\hline$\geq 4000 \mathrm{~g}$ & $1(2.3)$ & 0 & $1(5.9)$ & 0 \\
\hline Unknown & $2(4.5)$ & $1(4.5)$ & $1(5.9)$ & 0 \\
\hline \multicolumn{5}{|l|}{ Apgar score } \\
\hline 0 & $17(38.6)$ & $13(59)$ & $2(11.8)$ & $2(40)$ \\
\hline [1-3] to $1 \mathrm{~min}$ & $12(27.3)$ & $6(27.3)$ & $4(23.5)$ & $2(40)$ \\
\hline [3-7] to $1 \mathrm{~min}$ & $6(13.6)$ & $3(13.6)$ & $3(17.6)$ & 0 \\
\hline 10 to $5 \mathrm{~min}$ & $9(20.5)$ & 0 & $8(47)$ & $1(20)$ \\
\hline \multicolumn{5}{|c|}{ Non malformative neonatal pathology } \\
\hline Respiratory distress & $3(6.8)$ & 0 & $3(17.6)$ & 0 \\
\hline Neonatal suffering & $3(6.8)$ & $1(4.5)$ & $2(11.8)$ & 0 \\
\hline Intrauterine growth retardation & $11(25)$ & $4(18.2)$ & $5(29.4)$ & $2(40)$ \\
\hline Prematurity & $5(11.3)$ & $1(4.5)$ & $3(17.6)$ & $1(20)$ \\
\hline Newborn transfer & $3(6.8)$ & 0 & $3(18.8)$ & 0 \\
\hline \multicolumn{5}{|l|}{ Transfer service } \\
\hline Neonatal intensive care unit & $1(2.3)$ & 0 & $1(33.3)$ & 0 \\
\hline Pediatric ward & $2(4.5)$ & & $2(66.7)$ & \\
\hline \multicolumn{5}{|l|}{ Evolution at 6 months } \\
\hline Living & $7(16)$ & 0 & $7(41.2)$ & 0 \\
\hline Deceased & $17(38.6)$ & $9(40.9)$ & $6(35.3)$ & $2(40)$ \\
\hline Fetal death in utero & $17(38.6)$ & $13(59.1)$ & $2(11.8)$ & $2(40)$ \\
\hline Lost to follow-up & $3(6.8)$ & 0 & $2(11.8)$ & $1(20)$ \\
\hline
\end{tabular}

NTDs neural tube defects, \% percentage, $N$ number, WA week of amenorrhea, $g$ grams, min minute

\section{Discussion}

In our study, 44 cases of neural tube defect were reported, representing a prevalence rate of 10 per 10,000 births. This is a lower rate than those reported by previous Moroccan studies. Thus (Table 4) presents a comparative study of the rate of NTDs in different countries in the world and Morocco. The decrease in NTDs in Morocco is due to the implementation since
2008 by the health ministry, of a supplementation strategy to provide every pregnant women with $400 \mu \mathrm{g}$ of folic acid and a daily dose of $5 \mathrm{mg}$ to every women under antiepileptic treatment (sodium valproate, carbamazepine) or with a history of NTDs (had given birth to a baby with NTD, or NTD cases within her family) 2 months prior to conception and during the first trimester of pregnancy [30, 31]. 
Table 4 Comparative table of NTDs' prevalence rates per 10,000 births in different countries in the world and Morocco

\begin{tabular}{|c|c|c|c|c|c|}
\hline \multirow[t]{2}{*}{ Country and study period } & \multirow{2}{*}{$\begin{array}{l}\text { NTD's } \\
\text { prevalence } \\
\text { rates per } \\
10,000 \text { births }\end{array}$} & \multicolumn{3}{|c|}{ Specific prevalence rates per 10,000 births } & \multirow{2}{*}{$\begin{array}{l}\text { Incidence } \\
\text { rates per } \\
1000 \text { births }\end{array}$} \\
\hline & & Anencephaly & Spina Bifida & Encephalocele & \\
\hline \multicolumn{6}{|l|}{ In Africa } \\
\hline \multicolumn{6}{|l|}{ Algeria } \\
\hline$-2004-2006[7]$ & 75.3 & 32.2 & 42.8 & 0.3 & $7.5[8]$ \\
\hline - 2012-2013 [9] & 15.8 & & & & 1.58 \\
\hline Tunisia [10] & & & & & 2.2 \\
\hline Libya 1995 [11] & & 7.4 & 0.6 & & \\
\hline Congo [12] 1993-2001 & 10.2 & 1.1 & 6.8 & 2.3 & 1 \\
\hline Ghana [13] 1991-1992 & & 8.4 & 3.1 & & \\
\hline Nigeria [14] 1980-2003 & & 1.6 & 3.7 & & \\
\hline \multicolumn{6}{|l|}{ Morocco } \\
\hline - 2008-2011 [15] & $21.78-12.1$ & & & & \\
\hline - 2012-2015 [16] & 10.5 & & & & \\
\hline$-2011-2016$ & 10 & 5 & 3.8 & 1.1 & 1 \\
\hline In Europe 2011-2017 [17] & 10.08 & 4.05 & 4.91 & 1.12 & 1 \\
\hline \multicolumn{6}{|l|}{ France } \\
\hline (Rhône Alps) & 12.51 & 5.24 & 6.00 & 1.27 & 1.2 \\
\hline (Auvergne) & 11.73 & 4.82 & 5.48 & 1.43 & 1.17 \\
\hline Belgium (Antwerp) & 5.74 & 1.70 & 3.64 & 0.40 & 0.57 \\
\hline Germany (Mainz) & 13.11 & 4.63 & 6.94 & 1.54 & 1.3 \\
\hline Sweden & 7.12 & 2.64 & 3.76 & 0.72 & 0.7 \\
\hline Denmark (Odense) & 14.17 & 4.72 & 7.99 & 1.45 & 1.4 \\
\hline Italy (Emilia Romagna) & 5.36 & 1.74 & 2.70 & 0.93 & 0.5 \\
\hline Spain (Basque country) & 11.04 & 6.20 & 4.16 & 0.69 & 1.1 \\
\hline \multicolumn{6}{|l|}{ England and Wales } \\
\hline$-2000[18]$ & 16.3 & & & & 1.6 \\
\hline - 2004 [19] & 12.8 & & & & 1.3 \\
\hline \multicolumn{6}{|l|}{ In American continent } \\
\hline \multicolumn{6}{|l|}{ Costa Rica [20] } \\
\hline-1987 & 9.8 & & & & 0.98 \\
\hline-2012 & 4.8 & & & & 0.48 \\
\hline \multicolumn{6}{|l|}{ USA [21, 22] } \\
\hline$-1999-2007$ & 5.25 & 1.3 & 3.17 & 0.78 & 0.52 \\
\hline \multicolumn{6}{|l|}{$-1995-2002$} \\
\hline Hispanics & & 4.2 & 2.8 & & \\
\hline Non-Hispanic whites & & 3.4 & 2 & & \\
\hline Non-Hispanic blacks & & 2.9 & 1.8 & & \\
\hline Mexico 2008-2013 [23] & 3.2 & 1.52 & 1.39 & 0.28 & 0.32 \\
\hline \multicolumn{6}{|l|}{ Canada [24] } \\
\hline-1996 & 7.6 & 1.1 & 5.5 & 1.1 & 0.76 \\
\hline - 2004-2007 & 4 & 0.8 & 2.7 & 0.6 & 0.4 \\
\hline \multicolumn{6}{|l|}{ In Asia } \\
\hline India 2011-2012 [25] & 17.9 & 1.6 & 14 & 2.3 & 1.8 \\
\hline
\end{tabular}


Table 4 Comparative table of NTDs' prevalence rates per 10,000 births in different countries in the world and Morocco (Continued)

\begin{tabular}{llllll}
\hline Country and study period & $\begin{array}{l}\text { NTD's } \\
\text { prevalence } \\
\text { rates per } \\
\mathbf{1 0 , 0 0 0} \text { births }\end{array}$ & \multicolumn{2}{l}{ Specific prevalence rates per 10,000 births } & Encephalocele & $\begin{array}{l}\text { Incidence } \\
\text { rates per } \\
\mathbf{1 0 0 0}\end{array}$ \\
\cline { 4 - 6 } births
\end{tabular}

The disparity in NTD rates in Africa is due to several factors; distinctive characteristics in terms of geography, genetics, culture and nutrition in addition to differences in health policies between countries (i.e. whether or not a folic acid supplementation strategy has been implemented). The reported rates are also sensitive to the type, duration, sample size and methodology of the study.

In developed countries, this decrease in the rate of NTDs is due to the mandatory folic acid supplementation and fortification especially during the preconception period, early screening through prenatal diagnosis and therapeutic interruption of pregnancy.

In our study, we observed a female predominance especially in cases of anencephaly (sex ratio $=0.75$ ) which was similarly described by Houcher et al. [7]. On the other hand, we observe a male predominance in cases of spina bifida (1.33) which was also described by Rai et al. [32]. NTDs can have multifactorial causes; genetic or environmental, or resulting from an interaction between genetic and environmental factors. Recent studies have reached the conclusion that the presence of C677T coding gene 5.10- Methylene Tetrahydrofolate Reductase, an enzyme which affects folate synthesis, increases the risks of spina bifida and anencephaly in the fetus [33]. Other risk factors may be associated, notably diabetes and obesity [34, 35]. Some drugs, such as valproic acid, carbamazepine, fumonisin, trimethoprim and warfarine anticoagulant, can also cause NTDs. Valproic acid, for instance, is responsible for 2 to $3 \%$ of spina bifida cases [36]. Other risk factors have been identified such as hyperthermia, zinc deficiency and some cleaning products [37]. However, folate deficiency remains the most widely recognized risk factor and can be prevented with very simple measures. Certain risk factors for NTDs described in the literature were detected in our series, such as consanguinity (34\%), consumption of fenugreek and other plants (36\%), diabetes (4.5\%) and medication (2.2\%). A case-control study was conducted between 2008 and 2011 in Morocco which reported that the association of low socio-economic status was statistically significant in the occurrence of NTDs [15], this is due to malnutrition especially the deficiency of folic acid and insufficient monitoring of pregnancy, in our study 59\% of women belong to a low socio-economic population. Several studies have reported the role of consanguinity in the occurrence of congenital malformations. What is more, these malformations are twice as likely to occur in the case of first cousins [38]. According to Talbi et al., Morocco has one of the highest consanguinity percentage at $22.79 \%$ and a consanguinity coefficient of 0.0088 [39]. In our study, consanguinity was notified in different types of NTDs with an estimated rate of $34 \%$ and even $80 \%$ in first degree cases. This is a higher rate than the one observed by Bourouba et al. in Algeria where the consanguinity rate was 30\% [9], and by Golalipour et al. in Iran who reported a rate of $28 \%$ [29]. The consumption of fenugreek and other plants was primarily related to cases of anencephaly and spina bifida. Fenugreek (Trigonella foenum-graecum) is a medicinal and seasoning plant widely used in Moroccan as well as Mediterranean and Asian cuisine. In Morocco, this plant is consumed to treat several diseases and its seeds are used for pregnancy-related ailments such as vomiting as well as to stimulate appetite [40]. In their analysis of studies on the clinical association between fenugreek consumption and the occurrence of NTDs, A. Es Seddiki et al. reached the conclusion that this plant represents a major risk factor and had detrimental fetotoxic and teratogenic effects on the fetus [41].

In our series, we have identified a history of malformations within siblings (4.5\%) and within the family (6.8\%). This recurrence risk has been described in literature with rates ranging from 2 to $5 \%$ [42]. However, several studies have concluded that a folic acid supplementation during the periconceptional period reduces this recurrence risk by 40 to $80 \%$ [4, 43-48]. Other studies proved the efficiency of folic acid supplementation in reducing NTD rates when taken during the periconceptional period and the first trimester [49-51]. However, none of the women in our study received a folic acid supplementation during the periconceptional period and as much as $60 \%$ of them did not receive it during the first trimester of pregnancy.

The NTDs' antenatal diagnosis through obstetrical ultrasound allows us to identify the type of defect and any associated malformations. Thus, it enables a therapeutic decision and an informed discussion with the 
couple regarding options for in utero repair or a therapeutic interruption of pregnancy. In their study, Matuszewski et al. have observed a strong correlation between antenatal ultrasound data and postnatal examination of spinal dysraphism [52]. About two thirds (63\%) of NTD cases in our study were diagnosed antenatally with only 4 cases $(9.1 \%)$ who underwent a pregnancy termination procedure. This low rate is due to several factors, especially the couples' religious and sociocultural beliefs that reject resorting to pregnancy termination in case of fetal anomalies.

Furthermore, the rate of associated malformations varies, depending on the study, between 18 and $46 \%$ for anencephaly, 12 and $63 \%$ for spina bifida and exceeds $80 \%$ for encephalocele [53]. Matuszewski et al. and Toru et al. reported a rate of NTD-associated malformations at 32.7 and $32 \%$ respectively [52, 54]. In our study, about half of NTD cases presented multiple malformations; 13 cases of spina bifida were associated with other types of malformations which represents $76.5 \%$ of cases. This is higher than the rate of $33 \%$ reported by De Vigan et al. [53]. Among our cases of spina bifida, 7 cases or $53.8 \%$ were associated with at least one hydrocephalus which is in line with the figures reported by Alatise et al. and Kumar R. et al. at respectively 53.8 and $58.8 \%[55,56]$. Studies in developed countries have reported higher rate between 78 and $86 \%$ [57] or between 85 and 90\% [58].

Cases of fetal death in utero (FDIU) represented 38.6\% while 17 cases (38.6\%) died before or during the medical care. Our mortality rate of 3.8 per 10,000 total births with a fatality rate of $38 \%$ is significantly higher than the rate of $10 \%$ reported in literature [52]. This is mainly due to severe NTD cases especially of anencephaly and multiple malformations in addition to the challenges of providing adequate medical care to NTD cases in our context.

\section{Study limitations}

This study covers one medical center. In order to notify all abnormalities including functional abnormalities, it is necessary to make a long-term follow-up, which was not the case in the present study. Therefore, we need to consider a wider study which will allow us to assess the incidence rate at the national level, and to look into the implementation of primary preventive measures in order to assess the efficiency of folic acid supplementation and fortification during the preconceptional and pregnancy periods.

\section{Conclusion}

Through our study of NTDs' incidence at "Les Orangers" Maternity and Reproductive Health Hospital of Rabat, we observed a rate of 1 per 1000 births. Among the risk factors for NTDs described in the literature, consanguinity and the consumption of fenugreek are frequent in our context and require preventive actions. In order to reduce the rate of NTDs in our context, the prevention strategy implemented by the Ministry of Health should be further strengthened by enforcing an early folic acid supplementation during the preconception period, monitoring pregnancies, increasing women's awareness of the importance of consuming folate-rich food and banning any consumption of fenugreek during the first trimester of pregnancy. Finally, the implementation of a national program for prenatal NTD screening will allow us to provide more adequate medical care.

\section{Abbreviations}

NTDs: Neural tube defects; TIP: Therapeutic interruption of pregnancy; FDIU: Fetal death in utero; USA: United States of America

\section{Acknowledgments}

We would like to thank everyone who had contributed in this study.

\section{Authors'contributions}

ATI was responsible for the study concept and design. KF coordinated the study and interviewed the parents. KF and EB analyzed the data. KF led the drafting of this manuscript, with input from all authors. ATI and MHA supervised analysis of the data and contributed to the writing. ATI, MHA, EB, and AMA contributed to revision and final approval of the manuscript. All the authors have approved the present version of the manuscript.

\section{Funding}

Not applicable.

Availability of data and materials

The datasets used and /or analysed during the current study are available from the corresponding author on reasonable request.

\section{Declarations}

\section{Ethics approval and consent to participate}

The Ethics Committee For Biomedical Research, University Mohammed V Rabat, Faculty of Medicine and Pharmacy - Rabat, approved the study and the verbal consent procedure, $n^{\circ}: 20 / 16$. Ethics approval was granted in order to access the data. Oral consent to participate was obtained from the parents: Once a case has been confirmed, the doctor approaches the parents to explain the baby's situation and provide a prognosis. He also explains the method and objectives of our study in order to obtain an informed parents' consent. A majority of the interviewed women are illiterate and, for cultural reasons, they have provided a verbal (i.e. without signature) consent to participate in the study. Each couple has provided his consent after receiving the necessary explanations from a three-person team of medical personnel, oral explanations and a written document describing the information relevant to their consent and the contact details of the researcher were provided to each patient. This procedure has been approved by the ethics committee.

\section{Consent for publication}

Not applicable.

\section{Competing interests}

All the authors declare that they have no competing interests.

\section{Author details}

${ }^{1}$ Congenital Defects Research Team, Faculty of Medicine and Pharmacy, University Mohamed V Rabat, P.B: 174 Downtown Rabat, Rabat, Morocco. ${ }^{2}$ Laboratory of Biostatistics, Clinical \& Epidemiological Research, Faculty of Medicine and Pharmacy of Rabat, University Mohamed V Rabat, Rabat,

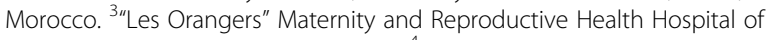
Rabat, CHU IBN SINA, Rabat, Morocco. ${ }^{4}$ Dysmorphology and Congenital Anomalies Unit, Pediatric Department 2, HER, CHU IBN SINA, Rabat, Morocco. 
${ }^{5}$ Center for consultations and external explorations, HER, CHU IBN SINA, Rabat, Morocco.

\section{Received: 17 August 2020 Accepted: 28 February 2021 Published online: 15 March 2021}

\section{References}

1. Christianson AL, Howson CP, Modell B. Global report on birth defects: the hidden toll of dying and disabled, children. White Plains: March of Dimes Birth Defects Foundation; 2006. https://www.marchofdimes.org/globalreport-on-birth-defects-the-hidden-toll-of-dying-and-disabled-children-fullreport

2. World Health Organization. Global health estimates (GHE)-Cause-specific mortality. 2015. http://www.who.int/healthinfo/global_burden_disease/ estimates/en/index 1.html.

3. World Health Organization. Global health estimates (GHE)-Disease burden 2015. http://www.who.int/healthinfo/global_burden_disease/estimates/en/ index2.html.

4. Blencowe H, Cousens S, Modell B, Lawn J. Folic acid to reduce neonatal mortality from neural tube disorders. Int J Epidemiol. 2010;39(Suppl. 1):i11021. https://doi.org/10.1093/ije/dyq028

5. Salih MA, Murshid WR, Seidahmed MZ. Classification, clinical features and genetics of neural tube defects. Saudi Med J. 2014;35(Suppl1):S5-S14 www. ncbi.nlm.nih.gov > articles > PMC4362100.

6. Saint Frison MH, Khung-Savatovsky S, Dupont C, Delezoide AL, Guimiot F. Les malformations cérébrales congénitales. Réanimation et soins intensifs en néonatologie. 2016;Chapitre 94:590-1. https://www.sciencedirect.com/ book/9782294739972/reanimation-et-soins-intensifs-en-neonatologie.

7. Houcher B, Begag S, Egin Y, Akar N. Neural tube defects in Algeria. INTECH; 2012. https://scolar.google.com/.

8. Houcher B, Bourouba R, Djabi F, Houcher Z. The Prevalence of Neural Tube Defects in Sétif University Maternity Hospital, Algeria-3 Years Review (20042006). Pteridines. 2008;19(1). https://doi.org/10.1515/pteridines.2008.19.1.12.

9. Bourouba R, Houcher B, Akar N. Risk factors of neural tube defects: A reality of Batna region in Algeria. Egypt J Med Hum Genet. 2018;19:225-9. https:// doi.org/10.1016/j.ejmhg.2017.10.003.

10. Khrouf N, Spång R, Podgorna T, Miled SB, Moussaoui M, Chibani M. Malformations in 10000 Consecutive Births in Tunis. Acta Paediatr Scand. 1986;75(4):534-9. https://doi.org/10.1111/j.1651-2227.1986.tb10245.x.

11. Singh R, Al-Sudani O. Major congenital anomalies at birth in Benghazi. Libyan Arab Jamahiriya, 1995. East Mediterr Health J. 2000;6:65-75 PMID: 11370343. www.ncbi.nlm.nih.gov > pubmed.

12. Ahuka OL, Toko RM, Omanga FU, Tshimpanga BJ. Congenital malformations in the North-Eastern Democratic Republic of Congo during civil war. East Afr Med J. 2006;8:95-9. https://doi.org/10.4314/eamj.v83i2.9395.

13. Anyebuno M, Amofa G, Peprah S, Affram A. Neural tube defects at Korle Bu Teaching Hospital, Accra, Ghana. East Afr Med J. 1993;70:572-4 PMID: 8181439. www.europepmc.org > article > med.

14. Airede Kl. Neural tube defects in the middle belt of Nigeria. J Trop Pediatr. 1992;38:27-30. PMID: 1573689. https://doi.org/10.1093/tropej/38.1.27.

15. Radouani MA, Chahid N, Benmiloud L, Elammari L, Lahlou K, Barkat A. Epidémiologie et facteurs de risque des anomalies de fermeture du tube neural: données marocaines. Pan Afr Med J. 2015;22:43. https://doi.org/10.11 604/pamj.2015.22.43.5158.

16. Daoudi D, Khattabi A, Harrag M, Meski FZ, Tazi MA. Situation épidémiologique des anomalies de fermeture du tube neural entre 2012 et 2015 dans la Province de Kénitra, Maroc. EPICLIN 2017 Saint-E tienne, 17-19 mai 2017. Rev Epidémiol Santé Publique. 2017;65S:S91-S104. https://doi. org/10.1016/j.respe.2017.03.099

17. European Surveillance of Congenital Anomalies (EUROCAT). Prevalence Tables; 2012. http://www.eurocat-network.eu/accessprevalencedata/preva lencetables.

18. Morris JK, Wald NJ. Prevalence of neural tube defect pregnancies in England and Wales from 1964 to 2004. J Med Screen. 2007;14(2):55-9. https://doi. org/10.1258/096914107781261945.

19. Morris JK, et al. Prevention of neural tube defects in the UK: a missed opportunity. Arch Dis Child. 2016;101:604-7. https://doi.org/10.1136/a rchdischild-2015-309226.

20. Maria, et al. Neural Tube Defects in Costa Rica, 1987-2012: Origins and development of birth defect surveillance and folic acid fortification. Matern Child Health J. 2015;19:583-90. https://doi.org/10.1007/s10995-014-1542-8.
21. Canfield MA, Mai CT, Wang P, O'Halloran A, Marengo LK, Olney RS, et al. The association between race/ethnicity and major birth defects in the United States, 1999-2007. Am J Public Health. 2014;104(9):e14-23. https://doi.org/10.2105/AJPH.2014.302098. www.ncbi.nlm.nih.gov > articles > PMC4151938.

22. Williams $L$, Rasmussen SA, Flores $A$, et al. Decline in the prevalence of spina bifida and anencephaly by race/ethnicity: 1995-2002. Pediatrics. 2005;116(3): 580-6. https://doi.org/10.1542/peds.2005-0592.

23. Navarrete-Hernández E, Canún-Serrano S, Valdés-Hernández J, Reyes-Pablo y AE. Malformaciones congénitas al nacimiento: México, 2008-2013. Bol Med Hosp Infant Mex. 2017;74(4):301-8. https://doi.org/10.1016/j.bmhimx.2017.02 003.

24. Dr Taylor G. Les anomalies congénitales au CANADA 2013, Rapport de surveillance sur la santé périnatale. Ottawa: Agence de la santé publique du; 2013. www.canada.ca > services > promotionsante. Accessed 20 Apr 2020.

25. Sarkar S, Patra C, Dasgupta MK, Nayek K, Karmakar PR. Prevalence of congenital anomalies in neonates and associated risk factors in a tertiary care hospital in eastern India. J Clin Neonatol. 2013;2:131-4. https://doi. org/10.4103/2249-4847.119998 PMID: 24251257

26. Zhang XH, Qiu LQ, Huang JP. Risk of birth defects increased in multiple births. Birth Defects Res A Clin Mol Teratol. 2011;91:34-8. https://doi.org/10.1 002/bdra.20725.

27. International Clearinghouse for Birth Defects Surveillance and Research. Annual report 2013. The International center on Birth Defects - ICBDSR Center. 2013:127. http://www.icbdsr.org/wp-content/annual_report/Report2 013.

28. Onrat ST, Seyman H, Konuk M. Incidence of neural tube defects in Afyonkarahisar, Western Turkey. Genet Mol Res. 2009;8:154-61 PMID: 19283682. www.ncbi.nlm.nih.gov > pubmed.

29. Golalipour MJ, Najafi L, Keshtkar AA. Neural Tube Defects in Native Fars Ethnicity in Northern Iran. Iran J Publ Health. 2010;39(3):116-23 www.ncbi. nlm.nih.gov > articles > PMC3481631.

30. Lutte contre les troubles dus aux carences en micronutriments. Manuel à l'usage des professionnels de santé 2008, Direction de la population, ministère de la santé, Maroc. www.sante.gov.ma > Publications > GuidesManuels > Documents. Accessed 22 Apr 2020.

31. Prévention et lutte contre les carences en micronutriments, Stratégie nationale de nutrition, guide destiné aux professionnels de santé, ministère de la santé, Maroc. www.sante.gov.ma > Publications > Guides-Manuels > Documents. Accessed 22 Apr 2020.

32. Sunil Kumar Rai, Royana Singh, Sharad Pandey, Kulwant Singh, Neeraj Shinde, Sangita Rai, et al. High incidence of neural tube defects in Northern part of India. 2016 Asian J Neurosurg 11, 4, October-December 2016 | Published by Wolters Kluwer - Medknow. https://doi.org/10.4103/1793-54 82.175628 Website: www.asianjns.org

33. Van der Put NM, Eskes TK, Blom HJ. Is the common 677C-->T mutation in the methylenetetrahydrofolate reductase gene a risk factor for neural tube defects? A meta-analysis. QJM. 1997;90(2):111-5. https://doi.org/10.1093/ qjmed/90.2.111.

34. Garne E, Loane M, Dolk H, et al. Spectrum of congenital anomalies in pregnancies with pregestational diabetes. Birth Defects Res A Clin Mol Teratol. 2012;94(3):134-40. https://doi.org/10.1002/bdra.22886.

35. Rasmussen SA, Chu SY, Kim SY, et al. Maternal obesity and risk of neural tube defects: a metaanalysis. Am J Obstet Gynecol. 2008;198(6):611-9. https://doi.org/10.1016/j.ajog.2008.04.021.

36. Ornoy A. Valproic acid in pregnancy: how much are we endangering the embryo and the fetus? Reprod Toxicol. 2009;28:1-10. https://doi.org/10.101 6/j.reprotox.2009.02.014.

37. Detrait ER, George TM, EtcheversHC, et al. Human neural tube defects: developmental biology, epidemiology, and genetics. Neurotoxicol Teratol. 2005;27:515-24. https://doi.org/10.1016/j.ntt.2004.12.007.

38. Sheridan E, Wright J, Small N, Peter C Corry, Sam Oddie, Catherine Whibley, et al. Risk factors for congenital anomaly in a multiethnic birth cohort: an analysis of the Born in Bradford study. Lancet. 2013:382(9901):1350-9. https://doi.org/10.1016/S0140-6736(13)61132-0.

39. Talbi J, Khadmaoui AE, Soulaymani AEM, Chafik AEA. Etude de la consanguinité dans la population marocaine. Impact sur le profil de la santé. Antropo. 2007;15:1-11 www.didac.ehu.es/antropo.

40. Taloubi LM, Rhouda H, Belahcen A, Smires N, Thimou A, Alaoui A. Mdaghri. An overview of plants causing teratogenicity: fenugreek (trigonella foenum graecum). IJPSR. 2013;4(2):1-4 www.ijpsr.com. 
41. Es Seddiki A, Messaouidi S, Amrani R. Le rôle du fenugrec dans la survenue d'anomalie de fermeture du tube neural : un signal d'alerte depuis le Maroc. Phytothérapie. 2017;15:155-8. https://doi.org/10.1007/s10298-017-1128-x.

42. Van Allen Ml, Fraser FC, Dallaire L, Allanson J, McLeod DR, Andermann E, et al. Recommendations on the use of folic acid supplementation to prevent the recurrence of neural tube defects. Clinical Teratology Committee, Canadian College of Medical Geneticists. Can Med Assoc J. 1993;149(9):1239-43. www.ncbi.nlm.nih.gov > Pubmed.

43. MRC Vitamin Study Research Group. Prevention of neural tube defects: results of the Medical Research Council Vitamin Study. Lancet. 1991;338: 131-7. https://doi.org/10.1016/0140-6736(91)90133-A.

44. Berry RJ, Li Z, Erickson JD, Li S, Moore CA, Wang H, et al. Prevention of neural-tube defects with folic acid in China. China-U.S. collaborative project for neural tube defect prevention. NEJM. 1999;341(20):1485-90. https://doi. org/10.1056/NEJM199911113412001.

45. Laurence KM, James N, Miller MH, Tennant GB, Campbell H. Double-blind randomised controlled trial of folate treatment before conception to prevent recurrence of neural-tube defects. Br Med J (Clin Res Ed). 1981; 282(6275):1509-11. https://doi.org/10.1136/bmj.282.6275.1509 PMID: 6786536.

46. Czeizel AE, Dudás I. Prevention of the first occurrence of neural-tube defects by periconceptional vitamin supplementation. N Engl J Med. 1992;327(26): 1832-5. https://doi.org/10.1056/NEJM199212243272602 PMID: 1307234.

47. De-Regil LM, Fernández-Gaxiola AC, Dowswell T, Peña-Rosas JP. Effect and safety of periconceptional folate supplementation for preventing birth defects. Cochrane Database Syst Rev. 2010;10(10):CD007950. PMID: 20927767. https://doi.org/10.1002/14651858.CD007950.pub3.

48. Khoshnood B, Blondel B. Prévention des anomalies de fermeture du tube neural Supplémentation en acide folique pendant la période périconceptionnelle ou fortification des produits alimentaires ? J Gynecol Obstet Biol Reprod. 2005;34:735-7 www.em-consulte.com > displayarticle > article.

49. Santos LMP, Lecca RCR, Cortez-Escalante JJ, Sancheza MN, Rodrigues HG. Prevention of neural tube defects by the fortification of flour with folic acid: a population-based retrospective study in Brazil. Bull World Health Organ. 2016;94:22-9. https://doi.org/10.2471/BLT.14.151365.

50. Lumley J, Watson L, Watson M, Bower C. Periconceptional supplementation with folate and/or multivitamins for preventing neural tube defects. Cochrane Database Syst Rev. 2001;3:CD001056. https://doi.org/10.1002/14 651858.CD001056.

51. Vidailhet M, Bocquet A, Bresson JL, Briend A, Chouraqui JP, Dupont C, et al. Prévention par l'acide folique des défauts de fermeture du tube neural : la question n'est toujours pas réglée. Arch Pédiatr. 2008;15:1223-31. https:// doi.org/10.1016/j.arcped.2008.04.012.

52. Matuszewski L, Perdriolle-Galet E, Clerc-Urmès I, Bach-Segura P, Klein O, Masutti JP, et al. Diagnostic prénatal des dysraphismes spinaux: corrélation des données anténatales et postnatales. J Gynecol Obstet Hum Reprod. 2017:46:291-6. https://doi.org/10.1016/j.jogoh.2016.10.009.

53. De Vigan C, Khoshnood B, Lhomme A, et al. Prévalence et diagnostic prénatal des malformations en population parisienne. Vingt ans de surveillance par le Registre des malformations congénitales de Paris. J Gynecol Obstet Biol Reprod. 2005;34:8-16. https://doi.org/10.1016/S03 68-2315(05)82665-1.

54. Toru HS, Sanhal CY, UzunO” C, Ocak GA, Mendilcioğlu I, Karaveli FS. Associated anomalies with neural tube defects in fetal autopsies. J Matern Fetal Neonatal Med. 2016;29:798-802. https://doi.org/10.3109/14767058.201 5.1019456.

55. Alatise OI, Adeolu AA, Komolafe EO, Adejuyigbe O, Sowande OA. Pattern and Factors Affecting Management Outcome of Spina Bifida Cystica in IleIfe, Nigeria. Pediatr Neurosurg. 2006;42:277-83. https://doi.org/10.1159/ 000094062.

56. Kumar R, Singhal N. Outcome of Meningomyelocele / Lipomeningomyelocele in Children of Northern India. Pediatr Neurosurg. 2007;43:7-14. https://doi.org/10.1159/000097518.

57. Giuseppe Talamonti MD, Giuseppe D'Aliberti MD, Massimo Collice MD. Myelomeningocele: long-term neurosurgical treatment and follow-up in 202 patients. J Neurosurg. 2007. https://doi.org/10.3171/PED-07/11/368.

58. Fobe JL, Rizzo AM, Silva IM, Da Silva SP, Teixeira CE, De Souza AM, Fernandes A. IQ in hydrocephalus and myelomeningocele. Implications of surgical traitement. Arq Neuropsiquiatr. 1999;57(1):44-50. https://doi.org/1 0.1590/s0004-282x1999000100009.

\section{Publisher's Note}

Springer Nature remains neutral with regard to jurisdictional claims in published maps and institutional affiliations.

\section{Ready to submit your research? Choose BMC and benefit from:}

- fast, convenient online submission

- thorough peer review by experienced researchers in your field

- rapid publication on acceptance

- support for research data, including large and complex data types

- gold Open Access which fosters wider collaboration and increased citations

- maximum visibility for your research: over $100 \mathrm{M}$ website views per year

At BMC, research is always in progress.

Learn more biomedcentral.com/submissions 